\title{
تقييم فاعلية التنسيق في الإدارة الرياضية (قسم التدريب) \\ (دراسة تطبيقية على الإدارة العامة للدفاع المدني بالعاصمة المقدسة)
}

Evaluating the effectiveness of coordination in sports management (training department) (an applied study on the General Administration of Civil Defense in the Holy Capital) إعداد الباحث/تركي فيصل عبد المحسن الثريف

ماجستير الإدارة الرياضية، كلية الأعمال ـ رابغ، جامعة الملك عبدالعزيز ، المملكة العربية السعودية Email: tsfwn2001@hotmail.com

يهدف البحث إلى التعرف على واقع على تقييم أداء الإدارة الرياضية وفاعلية التنسيق بقسم التنديب للإدارة

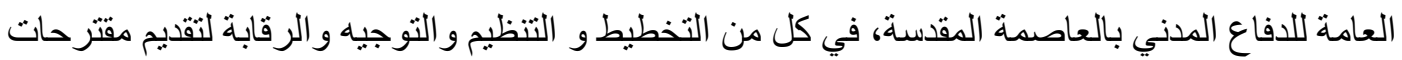
لتطوير أداء القسم ولتحقيق ذلك استخدم الباحث المنهج الوصفي مطبقًا أداة الاستبانة على المنسوبين بإدارة

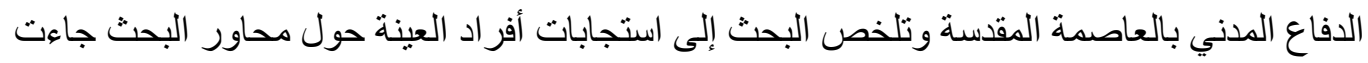

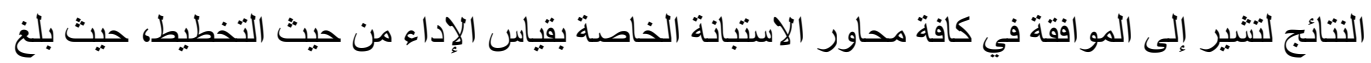

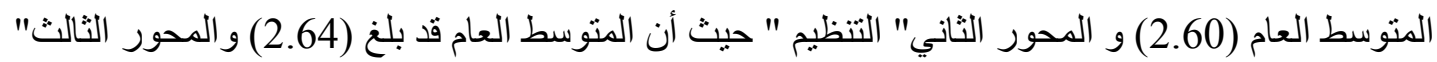

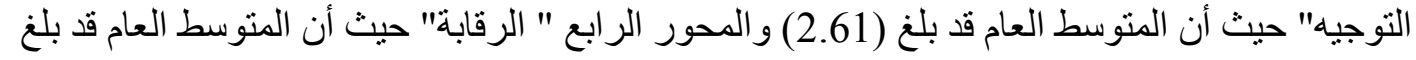
(2.56) أما من حيث دلالة الفروق حسب متغير المؤهل الدراسي و الوظيفة عدم وجود فروق ذات دلالة إحصائية عند مستوى (0.05) بين متوسطات استجابات أفراد العينة حول محاور الاستبانة الأربعة في حين جاءت دالة في متغير الدورات التنريبية.

الكلمات المفتاحية: تقييم، أداء الإدارة الرياضية، قسم التدريب، الإدارة العامة للافاع المدني بالعاصمة المقدة، تتسيق، فاعلية، الإدارة الرياضية، المجال العسكري. 


\title{
Evaluating the effectiveness of coordination in sports management (training department) (an applied study on the General Administration of Civil Defense in the Holy Capital)
}

\begin{abstract}
:
The research aims to identify the reality of evaluating the performance of the sports administration in a department for training of the General Administration of Civil Defense in the Holy Capital, in planning, organizing, directing, and controlling, to present proposals for the development of the department's performance, and to achieve this, the researcher used the descriptive approach, applying the questionnaire tool to the employees of the Department The civil defense in Makkah Al-Mukarramah, and the research concluded with the responses of the sample members about the research axes. The results indicated approval in all aspects of the questionnaire related to measuring performance in terms of planning, where the general average reached (2.60), and the second axis is "organization" as the general average was It reached (2.64), the third axis is "guidance" as the general average reached (2.61), and the fourth axis "control" as the general average reached (2.56). As for the significance of the differences according to the variable of academic qualification and job, there are no differences Statistical significance at the level of (0.05) among the averages of the responses of the respondents around the four questionnaire axes, while it was a function of the training courses variable.
\end{abstract}

Keywords: Evaluation, performance of the sports administration, the training department, the General Directorate of Civil Defense in the Holy Capital, coordination, effectiveness, sports management, the military field. 
الإدارة نشاط حتمي لكل مجمو عة بشرية هادفة، فوجود مجمو عة من الأفر اد معاً وقدر آخر من الأمو ال النقدية و العينية لا يكفيان في حد ذاتهما لإنجاز أي هدف، حتى لو كان هذا الهدف قد تم تحديده، و أنه من الطبيعي أن يتساءل كل فرد من أفراد المجموعة عن ماهية العمل المطلوب منه وكيفية إنجازه وميعاد هذا الإنجاز. (العطيات، السعود، 2009، ص 266) لذلك فإن الإدارة المؤسسية التي لا تعتمد في نهجها على العمليات الإدارية الأساسية من تخطيط سليم، وتنظيم و اضح و اتصال فاعل، و اتخاذ قرار ات سليمة ومتابعة مستمرة، أو لو لون التي لا تدرك الأسس العلمية والعملية لهذه العمليات الإدارية الأساسية و لا تعمل بها، فإنها بطبيعة الحال قد تفثل في تحقيق أهدافها. وقد اتفق معظم الباحثين على أن تقييم الأداء هو جزء أساسي من عملية الإدارة، وهي المرحلة التي يتأكد منها مديرو الإدارات العليا أن اختبارهم قد حقق أهداف المشروع وغاياته، ويتم بموجبها مقارنة الأداء الفعلي بالنتائج المر غوبة، وتقييم مدى التقدم الذي أنجز باعتبار أن تقييم الأداء مسؤولية أساسية للمدر اء، وذللك يفرض عليهم المحافظة على كفاءة وفاعلية منشأتهم باستمر ار (ياغي، 1994). يعد التدريب من المفاتيح الأساسية لتطوير وتحسين العنصر البشري من خلال نزويده بالمعلومات والمعارف التي تنقصه، وتتمية قدراته ومهار اته، وتعديل اتجاهاته وقناعاته، وذللك في سبيل رفع مستوى كفاءته وتحسين أدائه وزيادة إنتاجه وتحقيق أهدافه الخاصة و الوظيفية إلى أقصى قدر ممكن من الجودة والسر عة و الاقتصـاد. (مساعدة، 2008، ص 8). ولهذا يحتل التدريب أهمية قصوى بوصفه عنصر ا رئيسيا في عملية التنمية الإدارية ولذلك فإن نجاح التدريب في تحقيق أهدافه يتطلب عناية فائقة في التخطبط و التنفيذ والمتابعة ضمانا لتحقيق الغايات المنشودة، حتى التى يتمكن الفرد العامل من تأدية عمله بالثكل الأمثل. (الخطيب، 2006، ص 287) وبناءً على ما سبق فأن الاهتمام من جانب الإدارة العامة للدفاع المدني بالعاصمة المقدة بالاهتمام بقسم التدريب بها لما له من أثر

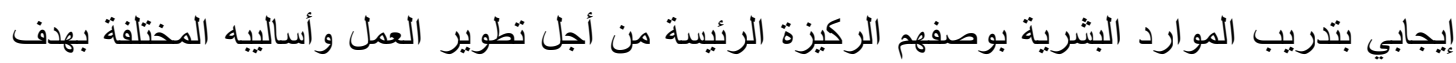
التحسين والتطوير المستمر لمواكبة كافة التطورات والتغيرات الحاصلة في كافة الميادين والمجالات وبالإضافة لمو اكبة ثورة المعلومات و الاتصالات التي أصبحت أمرًا ضروريًًا على كافة المؤسسات و أصبحت وله

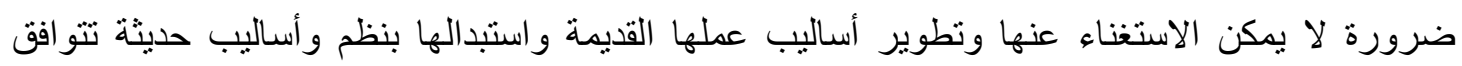
ومتطلبات العصر المستجدة.

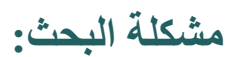
لاحظ الباحث أن هناك نقصاً واضحاً في الدراسات التي تهتم بتقييم الأداء في التدريب بالإدارة العامة للدفاع المدني بوزارة الداخلية السعودية، وذلك من خلال مر اجعة العديد من الدوريات والمجلات العلمية والعربية و الإقليمية، فتولدت لديه الرغبة في إجر اء هذا البحث على قسم التدريب في مدينة مكة. 
كما أن استخدام الأساليب العلمية في تقييم الأداء المؤسسي ينسجم مع الاتجاهات الحديثة للدول المتقدمة التي تبني خططها وتقو أهدافها وتعدل من بر امجها وفق بيانات و إحصائيات دقيقة، ولذلك يمكن الوقوف على مدى تحقيق البرامج والخطط لأهدافها ووضع الحلول لتطوير الأداء كاملاً أو العلاج لتعديل المسار. ويأتي هذا البحث بهدف التعرف على أداء الإدارة بقسم التدريب للإدارة العامة للافاع المدني بالعاصمة المقسة، وتتحدد مشكلة البحث في التساؤل الرئيسة التالية:

ما تقييم أداء الإدارة الرياضية بقسم لتدريب للإدارة العامة للافاع المدني بالعاصمة المقدسة؟ ويتفرع منه

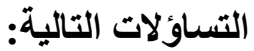

1. ما تقييم عملية التخطيط للإدارة الرياضية بقسم التدريب للإدارة العامة للدفاع المدني بالعاصمة

2. ما تقييم عملية التنظيم للإدارة الرياضية بقسم التدريب للإدارة العامة للافاع المدني بالعاصمة المقدة؟ 3. ما تقييم عملية التوجيه للإدارة الرياضية بقسم التدريب للإدارة العامة للدفاع المدني بالعاصمة

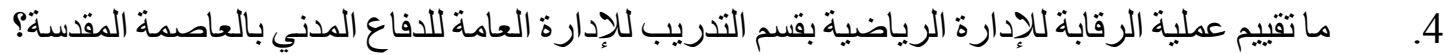
5. ما أهم المقترحات اللازمة لتطوير أداء الإدارة الرياضية بقسم التدريب للإدارة العامة للافاع المدني

يهدف البحث إلى التعرف على تقييم أداء الإدارة الرياضية بقسم لتدريب للإدارة العامة للدفاع المدني بالعاصمة المقدسة، في كل من التخطيط، التنظيم، التوجيه، الرقابة، لتقديم مقترحات لتطوير أداء القسم.

\section{أهمية البحث:}

1. وتتجلى أهمية البحث في أن الأداء الإداري و الفني للإدارة الرياضية بقسم التدريب بالإدارة العامة للدفاع المدني، و التي يجب أن تتبني أسس علمية بهدف بناء قسم بطريقة علمية ومنهجية من خلال أسس خاضعة لعملية تقييم فاعلة وذلك لتطوير الجوانب الحيوية والمهمة و الارتقاء بخبر اتهم إلى المستويات المطلوبة في الإدارة الرياضية بالقسم. 2. أنه من البحوث و الدر اسات التى تهتم بتطوير الإداء في مجال الرياضية و إدارتها، و التركيز على قسم التدريب بإدارة الدفاع المدني بالعاصمة المقدة، وهو ما يمكن أن يحدث حر اكًا إيجابياً في تناول معوقاتها

$$
\text { و العمل على حلها بشكل سريع. }
$$

3. قد تُسهم نتائج البحث في تمكين ومساعدة المسؤولين عن الرياضة بقسم التدريب لاتخاذ القرارات المناسبة فيما يخص مستوى الإداء بالقسم و العمل على حل مشكلاتها إن وجدت أو بهدف التحسين و التطوير. 
قروض البحت:

هل توجد فوق ذات دلالة إحصائية عند مستوى دلاله (0.05) حول تقييم أداء الإدارة الرياضية بقسم التدريب للإدارة العامة للدفاع المدني بالعاصمة المقدة، تُعزى لمتغير (المؤهل الدراسي، الدورات التدريبية،

الوظبفة)

مستوى أداء الإدارة الرياضية بقسم التدريب للإدارة العامة للدفاع المدني بالعاصمة المقدة يو اكب

التحو لات الرياضية بوزارة الداخلية.

حدود البحث:

الحد البشري، العاملين في بقسم التدريب للإدارة العامة للافاع المدني بالعاصمة المقدة.

• • الحد المكاني، قسم التدريب للإدارة العامة للدفاع المدني بالعاصمة المقدسة.

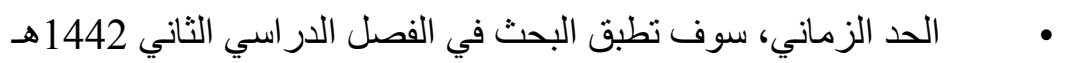

مصطلحات البحث:

تقييم:

فحص تحليلي انتقادي شامل مخطط و لأهداف وطر ائق التشغيل واستخدام الموارد البشرية و المادية بهدف التحقق مـن كفاءة واقتصادية الموارد و استخدامها أفضل استخدام وبأعلى كفاءة لتحقيق الأهداف المرسومة

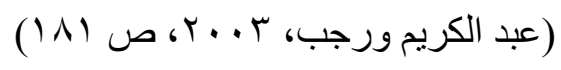

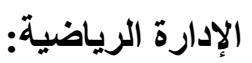

المهار ات المرتبطة بالتخطيط و التنظيم والتوجيه و المنابعة والميز انيات والقيادة و التقييم داخل مؤسسة تقدم خدمة رياضية و أنشطة بدنية أو ترويحية". نجد في المجال الرياضي أنا الإداري يعتمد في تحقيق أهدافه على هلى ستة عناصر هي: المنشأة، القيادة، البرامج، الميز انيات، المستخدمين. و عليه إذا ما توفرت للإداري في المجال الرياضي هذه العناصر الأولى كان عليه أن يسعى لإيجاد العنصر السادس وهو " تنظيم إدارة العمل (حسام

$$
\text { قسم التدريب: 1997، ص7) }
$$

يعرف إجر ائيًا بأنه " يقوم قسم التدريب على اختيار المتدربين وفق نماذج محدده، والعمل على تنفيذ الخطة

هي القدرة على مضاعفة النتائج النهائية للمنظمة من خلال الاستخدام الأمنل لكافة الوسائل المتاحة في البيئة

$$
\text { الداخلية و الخارجية. }
$$


هو الربط بين أعمال أقسام الوحدة أو الوحدات وتحريك هذه الأقسام في الوقت المحدد بحيث ييذل كل قسم منها قصارى جهدها في سبيل الوصول الى الغاية أو الهذف المقصود. الإدارة العامة للافاع المدني بالعاصمة المقدسة ((الدفاع المدني)): يعرفها الباحث إجرائًا بأنها الجهة المعنية بالقيام بمجموعة الإجراءات والأعمال اللازمة لحماية السكان

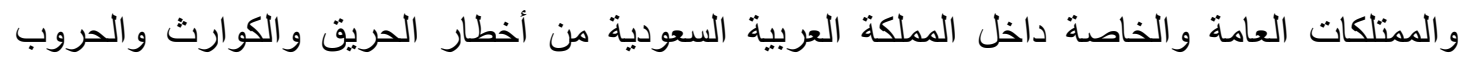
و الحوادث المختلفة و إغاثة المنكوبين وتأمين سلامة المواصلات وسير العمل في المرافق العامة وحماية مصادر الثروة، وذلك في زمن السلم وفي حالات الحرب و الطوارئ.

القصل الثاني الإطار النظري والدراسات السابقة الإطار النظري

\section{مفهوم تقييم الأداء: - مفئ}

التقييم بمعناه المبسط هو تقدير موقف ما في ضوء دراسة مدى تحقيق هذا الموقف أو المجال لهدف محدد،

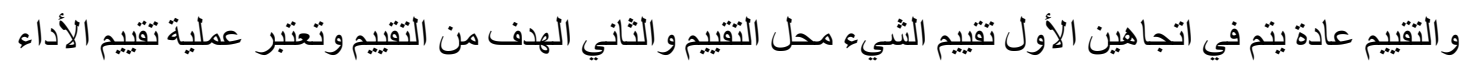
مرحلة من مر احل العملية الإدارية التي تبدأ بتحديد الأهداف ثم وضع خطة التنفيذ مع ضرورة وجئ وهود خطة رقابية علي عملية التنفيذ بهدف تقييم كفاية وفعالية تحقيق الأهداف.(حامد، 2009، صريكية 1150) ويمكن تعريف

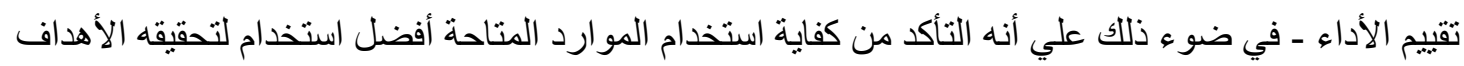
المخططة من خلال در اسة مدى جودة الأداء، واتخاذ القرارات التصحيحية لإعادة توجبه مسار ات الأنشطة

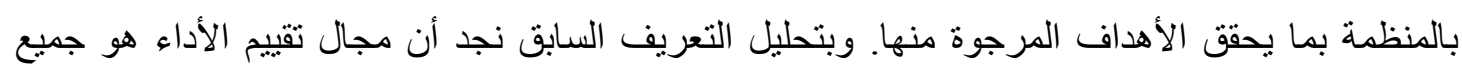
الأنشطة داخل المنظمة في ضوء المعلومات الرقابية التي تم التوصل إليها وذلك بهدف التأكد من أن الأنشطة

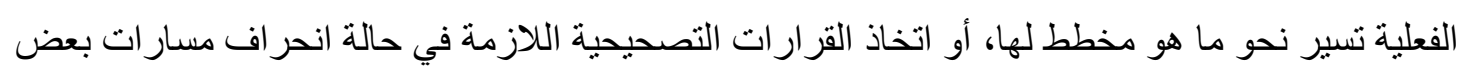

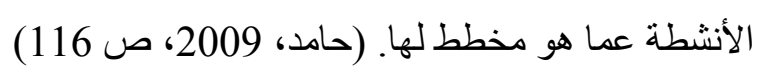

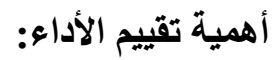
إن لعملية تقييم الأداء أهمية كبيرة ودور اً بارزاً في أقسام التدريب وتبرز هذه الأهمية في إدارة الدفاع المدني. ويمكن إجمال أهمية تقييم كفاءة الأداء في الآتي: 1. إن لعملية تقييم كفاءة الأداء دور اً كبير اً ومطلوباً في كل وقت وفيم وفي أي نظسام اقتصادي من أجل معرفة مو اطن الخلل لمعالجتها ثم تتمية الخواص الايجاييـة و العمل على تطوير ها.

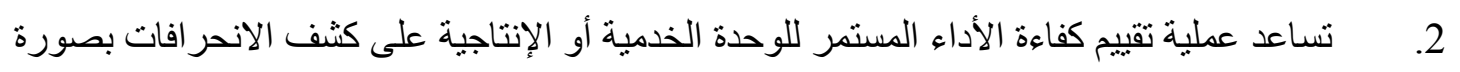
سريعة عند بدايتها مؤدية بذلك إلى اتخـاذ الخطوات العلاجية السريعة في تقدير الانحر افات التي تحدث

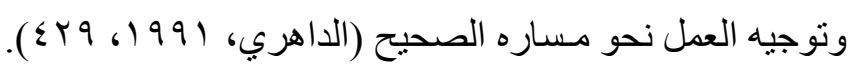


3. تساعد مؤشر ات الأداء على تزويد المستويات الإدارية المختلفة بوسائل قبـاس وتخطبط كفاءة الأداء لنشاطاتهم، لذلك نجد أن قرار اتهم ترتكز على حقائق وضعية وليس على تخمينات شخصية.

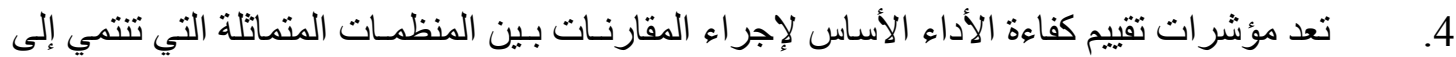

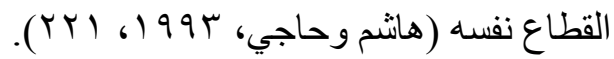
5. توفر عملية تقييم كفاءة الأداء المنافسة بين المنظمات المتماتلـة نحو العهل المبدع، فهي نوع من الحو افز ووسيلة لتكوين الشعور بالمسؤولية والشعور بالانتماء إلى الجهة التي يعمل بها الفرد. 6. عد عملية تقييم كفاءة الأداء الأساس في تحديد بر امج التدريب والأجور و المكافآت (سلمان،

.(^ ‘. Y.. أهمية الإداء بإدارة التدريب بإدارة الدفاع المدني: تنقسم أهمية الإداء بإدارة التدريب بإدارة الدفاع المدني إلى قسمين:

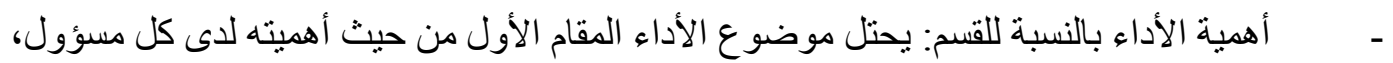
حيث يمثل الأداء أحد العوامل المهية التي تستخدم في تقييم المنظمة التي يدير ها أو ير أسها أو يشرف عليها. لذللك نجد أن جميع المسؤولين عن التنظيمات المختلفة يهتمون اهتماما كبير ا بأداء العاملين في هذه التنظيمات، ذلك لأن الأداء لا يعد انعكاسا لقدر ات كل فرد ودافعيته فحسب، و إنما هو انعكاس لأداء هذه التنظيمات ودرجة فاعليتها أيضا. - أهمية التدريب ودوره في تحسين أداء العاملين: ان التدريب هو النشاط الذي توليه المنظمة اهتماما كبير ا، حيث يهدف إلى تنمية قدر ات العاملين في العمل، ومن خلاله يزود الفرد بالمعلومات و المهار ات الجديدة المطلوبة لتحقيق استر اتيجية المنظمة في البيئة. إذا طبيعة التغيرات التي تعيشها المنظمات في الوقت الحاضر سواء كانت تكنولوجية أو تتظيمية أصبحت تفرض عليها ضرورة نو افق قدر ات العاملين مع ما يستجد من هذه التطور ات بغية تحقيق ما تصبو إليه المنظمات، و أصبح الزاما عليها أن تفتش عن برامج التدريب المناسبة للعاملين في مر اكز التدريب المختلفة. كما ينظر إلى وظيفة التدريب على أنها الوظيفة المكملة للتعيين، فلا يكفي أن تقوم المنظمات باختبار الموظفين وتعيينهم. إنما يجب إعداد هؤلاء الأفراد وتتمية قدر اتهم على أداء الأعمال المسندة إليهم ومساعدتهم في إكساب الجديد من المعلومات و المعارف وتزويدهم بالأساليب الجديدة لأداء الأعمال وصقل مهار اتهم. (الخطيب،2006، ص ـ288). وللتدريب تأثثر ات متعددة على أداء العاملين ومن أهمها ما يلي: 1. رفع مستوى الأداء وتحسينه من الناحية الكمية و النو عية. 2. تقوية العلاقات الإنسانية بين الأفر اد وتطوير اتجاهاتهم. 3. تتمية شعور العاملين بالانتماء و الو لاء للمنظمة. 
4. تخفيض معدلات كل من الغياب ودور ان العمل. (إبر اهيم، 2006، ص.31).

5. توعية العاملين بأهمية التدريب، و إكسابهم القدرة على البحث عن الجديد و المستحدث في شنى

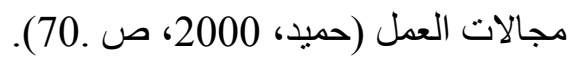

وظائف الإدارة الرياضية:

لا تختلف وظائف الإدارة في الإدارة الرياضية عن عنها في الأنظمة الإدارية، إلا أنها تتميز بارتباطها بالهدف الجانب الرياضي و التدريب وخاصة في مؤسسة إدارة الدفاع المدني، و هي على النحو الذي حدده علي، و عبد الرحيم (2009، ص صب2330-360)، كما يلي:

\section{وظيفة التخطيط Planning:}

يهنم التخطيط بتحديد الو اقع، والأهداف التي تسعى المؤسسات إلى تحقيقها، و الوسائل التي تستخدمها لتحقيق تلك الأهداف؛ لذا فإن التخطيط عملية تأخذ في الاعتبار نقاط القوة والضعف، و الفرص و المخاطر التي تحيط بالمؤسسة.

\section{وظيفة التظيم Organizing: و}

إن التنظيم هو نرتيب الأنشطة بطريقة تسهم في تحقيق أهداف المؤسسة، وهو الذي يعطيها شخصيتها ومميز اتها الإدارية، ويعزز من وزنها وقدرتها على الاستجابة للتغير ات في بنيتها الداخلية والخارجية. ويعد التنظيم القوة الأكثر صلابة في الإدارة، باعتبار أن التطور الحقيقي في الإدارة برجع أساساً للتطور في التي التنظيم؛ فهو الذي يعطي المؤسسة شخصيتها وميزتها، من خلال عناصره الخمسة المتمثلة في الهيكل التنظيمي، وسلسلة الأوامر بين المستويات التنظيمية، والرسمية التنظيمية، و المركزية و اللامركزية، و التقسيم الإداري. والحقيقة أنه في ظل الإدارة الإلكترونية ينظر إلى هذه العناصر على أنها قيود تحد من حرية

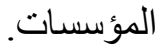

التوجيه:

إن المنهج الإسلامي قائم على أن وجود الرجل المناسب في المكان المناسب هو واجب شرعي وضامنًا لسلامة العمل وحسن الأداء والإسلام يربي الفرد على الإحسان والإتقان، و لا يسود الأمر إلا لأهله، كما فعل النبي صلى الله عليه وسلم ـ مع أبي ذر عندما طلب منه أن يوليه فقال له: (إنك ضعيف و إنها أمانة، و أنها يوم 


\section{وظيفة الرقابة Controlling:}

تركز الرقابة التقليدية على الماضي، وتهتم بالمقارنة بين الأهداف و المعايير المحددة من ناحية، و الأداء الفعلي من ناحية أخرى، لتحديد الفجوة الزمنية بين اكتشاف الانحر اف وتصحيحه.

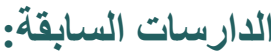

- جاءت در اسة إمام (2019).بعنوان " تقييم الأداء كمدخل لرفع كفاءة أداء العاملين: در اسة ميدانية مقارنة بين شركات صناعة الغزل و النسيج المصرية وشركات صناعة الغزل و النسيج الأجنبية". هدفت هذه الدر اسة إلى قياس أثر تقييم الأداء على كفاءة أداء العاملين مقارنة ما بين العاملين في شركات صناعة الغزل والنسيج في مصر وشركات صناعة الغزل و النسيج الأجنبية، كما هدفت الدر اسة إلى تقديم بعض التوصيات التي تساهم في الاهتمام بتقييم الأداء مما يجعله يلعب دورا هاما في تطوير المهارات و الخبرات و المعرفة لدى العاملين مما ينعكس بالدور الإيجابي على كفاءة الأداء العام للعاملين، ويتكون مجتمع الدر اسة من الأفر اد العاملين داخل الثركات المصرية و الثركات الأجنبية وتتكون من (312) مفردة بالثركات المصرية و(326) مفردة بالثركات الأجنبية، وقد تم استخدام مجموعة من الأساليب الإحصائية أهمها معامل ألفا كرونباخ وتحليل الانحدار الخطي البسيط، وتوصلت الدراسة إلى أنه هناك علاقة ما بين تقييم الأداء و عناصر كفاءة أداء العاملين بدرجات متفاونة داخل شركات صناعة الغزل و النسيج في مصر وشركات صناعة الغزل و النسيج الأجنبية فكلما زاد الاعتماد علي تقييم الأداء كلماز ادت كفاءة أداء العاملين، وأوصت الدر اسة بضرورة الاهتمام بتقييم الأداء داخل شركات صناعة الغزل و النسيج خاصة في الثركات المصرية والاستفادة من خبرات الثركات العالمية، لما لذلك من أهمية كبيرة لتحقيق أهداف الثركات. أما در اسة أحمد(2018) بعنوان " تقييم أداء البنوك المصرية باستخدام نظام التقييم المصرفي الأمريكي: در اسة مقارنة بين البنوك العامة و الخاصة" هدفت الدر اسة

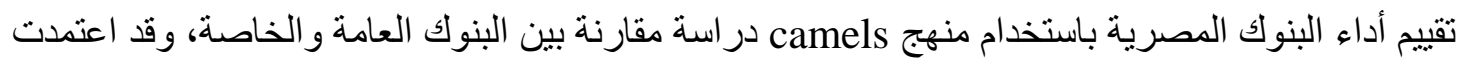
الدراسة على تقييم أداء البنوك باستخدام منهج Camels من حيث كفاية رأس المال وجودة الأصول و الربحية والسيولة وأخبراً عنصر الإدارة، كما هدفت الدراسة إلى تحليل البيانات السنوية لمؤشر الربحية للبنوك

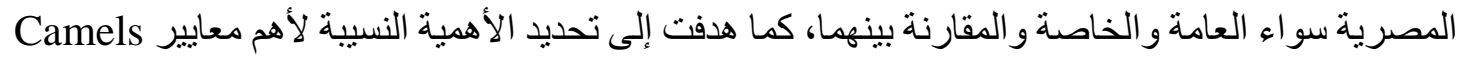
في تقييم أداء البنوك المصرية سو اء العامة أو الخاصة و التعرف على تقييم أداء البنوك باستخدام منهج Camels ولتحقيق أهداف هذه الدراسة تم الاعتماد على طريقة جمع المعلومات المالية عن البنوك تحت الدراسة (9 بنوك) سبعة بنوك خاصة و اثنين بنك عام بهدف تحديد النسب المالية المطلوبة للدراسة وذللك خلال الفترة 2010 إلى 2015 وتحليل البيانات المالية لهذه البنوك، وقد توصلت الدراسة إلى أن تقييم أداء البنوك باستخدام Camels Camels ينميز بعناصر مالية وفنية و إدارية يمكن من خلالها تقييم أداء البنك. وباستخدام تحليل الانحدار 
أظهرت نتائج الدر اسة وجود أثر إيجابي ذات دلالة إحصائية بين الربحية و أداء البنوك التجارية العامة مقارنة بالبنوك الخاصة. وقد أوصت الدراسة بضرورة قيام إدار ات البنوك التجارية المصرية بتبني برامج لتطوير وتحسين مستوى الأداء فيها ما تقدمه من خدمات وخاصة مع زيادة المنافسة في السوق المصرفية وبروز جودة الخذمات كميزة تتافسية في هذا السوق ومتابعة التحليل المالي للبنوك وخصة تللك النظم المتخصصة مثل نظام Camels و الاستفادة من خبر ات الدول و البنوك العالمية في هذا المجال.

ـ في حين جاءت دراسة آدم (2016). أثر التدريب في تطوير أداء العاملين: دراسة حالة الصندوق القومي للتأمين الصحي "و لاية النيل الأبيض" بهدف التعرف على الجوانب العلمية للتدريب في تنمية وتطوير العاملين، و التعرف كذللك على الدور الذي يلعبه التأمين الصحي في تنمية وتطوير أداء العاملين. اعتمد الباحث على البيانات و المعلومات الرئيسة للتأمين الصحي كمصادر ثانوية من الكتب و الدوريات و البحوث التي أعدتها إدارة الصندوق القومي للنامين الصحي، كما اعتمد على الاستبانات كمصادر أولية والتي تم توزيعها للعينة المستهدفة. من أهم النتائج التي توصل إليها الباحث تتمثل، في عدم وجود دورات تدريبية واضحة ينظمها الصندوق القومي للتأمين الصحي تجاه منسوبيه. ومن أهم التوصيات التي توصل إليها الباحث تتمثل، في ضرورة تأسيس قسم للتدريب في الصندوق القومي للتأمين الصحي يقوم بتحديد وتصميم الاحتياجات التدرييية، و القيام بتتظيم دورات تدريبية بصورة مستمرة ورتيبة لكل العاملين دون استثناء توطئة لتقييم أداء العاملين بعد وقبل التدريب.

ـ در اسة العطيات، و السعود(2009). بعنوان " تقييم الأداء للاتحادات الرياضية الأردنية للعام 2005" هدفت

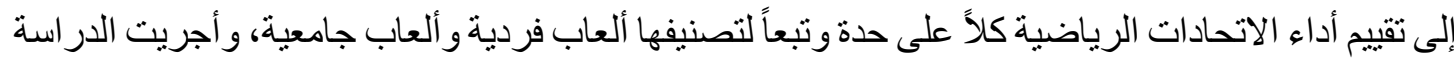
على 28 اتحاداً رياضياً يمثلون جميع الاتحادات الرياضية الأردنية، واستخدمت استمارة متخصصة لجميع البيانات ذات العلاقة بمختلف محاور التقييم، أظهرت نتائج الدراسة أن 98\% من الإنجاز ات و الميداليات كانت محصورة في بعض الاتحادات الفرعية، وكذلك أظهرت نتائج الدر اسة وجود ضعف و اضح في إعداد وتكوين الناشئين و الأشبال و غياب لمر اكز ومدارس الو اعدين فيما يقارب 80\% من الاتحادات مع أنهم أصل الرياضة الأردنية، كما أثنارت الدر اسة أيضاً إلى أن اتحادي القدم والسلة هما فقط اللذين برتبطان باتفاقيات مع شركات تسويقية. توصي الدر اسة بتشكيل دائرة تسويق خاصة بنشاطات اللجنة الأولمبية و الاتحادات الرياضية لتسويق البطو لات و التي قد تصل إلى حو الي 270 بطولة ونشاط سنوي للارتقاء بالمستوى الفني و الإداري وتوفير

$$
\text { السيولة و إنشهار الألعاب محلياً. }
$$

ـ كذلك أجرى العسيلي(2005) بعنوان "التقييم الإداري لأداء الاتحادات الرياضية الأولمبية في الأردن" بهدف

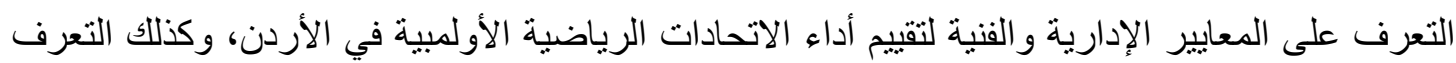
إلى فاعلية هذه الاتحادات في كل معيار من المعايير المقترحة. وقد أجريت الدراسة على أعضاء الهيئة العامة للاتحادات الرياضية الأولمبية في الأردن، 
واختيرت عينة الدراسة بالطريقة العمدية من ثمانية اتحادات رياضية أولمبية حيث بلغ عددهم 249 عضواً، وتكونت أداة الدر اسة من استبانة تمثل (9) محاور؟ وتوصلت الدر اسة إلى أن ضعف المو ارد المالية انعكس بهل سلبياً على تحقيق خطط وبر امج الاتحادات، وأن غياب الرقابة سبب في تدني مستوى العمليات الإدارية وتقويم الأجهزة الفنية والإدارية، وأن الخطة السنوية لا تحقق أهداف التخطبط الاستراتيجي، كما أن غياب مر اكز الو اعدين و الواعدات ساهم في انخفاض فرص اكتشاف الناشئين. - وجاءت در اسة الكعبي(2002). بعنو ان " اثر التدريب على تنمية الإدارة المحلية" و التى تهدف إلى التعرف على أسباب انخفاض مستوى البرامج التدريبية التي تتفذها وزارة الداخلية بسلطنة عمان و الذي أثر سلبا في سلوك و أداء العاملين بالوزارة، وقد استخدم الباحث في تحليل المشكلة أسلوب الاستقصاء من خلال عينة ممثلك من موظفي وز ارة الداخلية بلغت (1924) موظفا اقتصرت على موظفي الحلقة الثانية. وخلصت الدر اسة إلى تدني مستوى البرامج التدريبية التي تقدمها وزارة الداخلية بسلطنة عمان، والذي جاء نتيجة لعدم مر اعاة المسؤولين المعنيين بالعملية التدريبية بالوز ارة باتباع الأسس العلمية الحديثة في التخطيط و الإعداد الجيد لها.

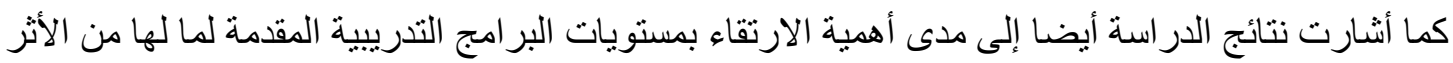
الفعال في ارتفاع مسنويات أداء العاملين وزيادة شعور هم. التعليق على الار اسات السابقة:

أوجه الاتفاق، يتفق البحث الحالي مع الدراسات السابقة في تطبيق أداة الاستبانة، والمنهج الوصفي،

$$
\text { و الهدف من البحث من تقييم الأداء داخل المؤسسات المختلفة. }
$$

أوجه الاختلاف، يختلف البحث الحالي في العينة وهي العاملين من إدارة الدفاع المدني بالعاصمة

المقسة، وكذلك الفترة الزمنية.

$$
\text { أوجه الاستفادة: استفاد الباحث من در اسة وتحليل الدر اسات السابقة بما يلي: }
$$

تحديد المحاور الرئيسية لأداة جمع البيانات، و عينة البحث، وأهم الأساليب الاحصائية المتبعة. الاستفادة من نتائج تللك الدر اسات في مناقثة نتائج هذا البحث، والتعرف على جو انب المشكلة موطن الدر اسة، وكذلك في تدعيم نتائج الدر اسة الحالية بنتائج الدر اسات السابقة. - اوضحت الدراسات السابقة ادوات جمع البيانات المختلفة التي استخدمت التقليدي منها و الحديث، وكذلك اوضحت هذه الدر اسات جو انب مهمه وجب التعرف عليها لحل المشكلات، وقياس درجة التحقق وتقييم

$$
\text { وتتميز در اسة البحث الحالي عن الدر اسات السابقة: }
$$


جميع الدراسات السابقة تناولت اهمية التسويق الرياضي واستر اتيجياته من جو انب عديدة ولكنها لم

$$
\text { تقييم الإداء لقسم التدريب بإدارة الدفاع المدني. }
$$

- لم تقترح أي من الدراسات السابقة استر اتيجية لتقييم الأداء لقسم التنريب و الإدارة الرياضية له في

حداثة البحث وتركيزه على اداء الادارة الرياضية بقسم التدريب بإدارة الدفاع ـالمدني في العاصمة

يتناول هذا الفصل كل من الإجر اءات الميدانية للبحث بداية من منهج البحث، وتحديد مجتمع وعينة البحث، وكذللك الوقوف على إعداد أداة البحث، وإجراءات تطبيقها، بالإضافة إلى تحديد الأساليب الاحصائية

سيعتمد البحث الحالي على المنهج الوصفي التحليلي، فهو المنهج المناسب لدراسة الظاهرة وبحثها "حيث يعتمد على دراسة ووصف الواقع ويهتم بوصفها وصفًا دقيقًا ويعبر عنها كيفيًا أو تعبيراً كميًا". (عبيدات، 2013، ص1831). حيث يتم در اسة و اقع الظاهرة كما هي، ويهتم بوصفها وصفًا دقيقا ويعبر عنها تعبيرًا كيفًاً أو كميًا ولذلك يتم استخدام هذا المنهج عن طريق جمع المعلومات والبيانات من خلال رجوع الباحث إلى الإطار النظري للبحث، وبالإضافة خبرة الباحث بهذا المجال ودر استه، ومن ثم استطلاع آراء مجتمع البحث وتحليل آر ائهم وتفسير هاوفقاً لإجر اءات البحث الميدانية، وذللك بهدف التعرف و اقع تقييم أداء الإدارة الرياضية بقسم لتدريب للإدارة العامة للافاع المدني بالعاصمة المقدة، في كل من التخطيط، التنظيم، التوجيه، الرقابة، لتقديم مقترحات لتطوير أداء القسم.

\section{مجتمع البحث وعينته:}

تمثل مجتمع البحث في كافة العاملين في بقسم لتدريب للإدارة العامة للدفاع المدني بالعاصمة المقدة، وذللك في العام الدراسي 1441 /1442ه، وقد تم اختيار عينة البحث بالطريقة العشوائية، وبلغ عددها (168) من العاملين بقسم التدريب. وفيما يلي يبين الجدول رقم(1) وصف لعينة البحث وتوزيعها حسب متغير ات البحث 
جدول (1)

توزيع أفر اد العينة البحث حسب متغير ات البحث

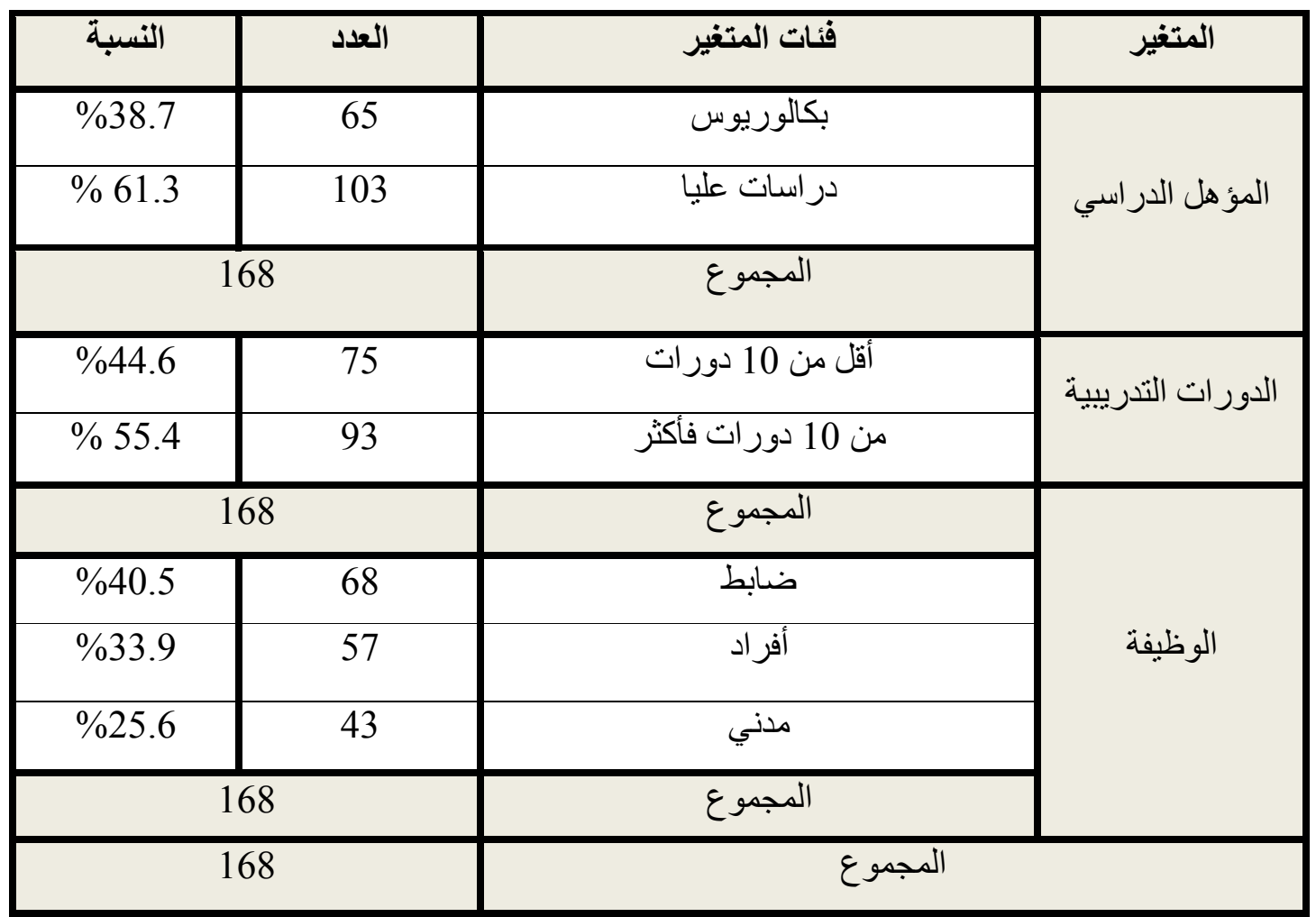

يتبين من الجدول (1) السابق، أن عدد افر اد العينة ومن حيث المؤهل الدر اسي فعدد الحاصلين على بكالوريوس (65) بنسبة (38.7\%) و الحاصلين على در اسات عليا (103) بنسبة (61.3\%). ومن حيث الدور ات التدريبية أقل من 10 دورات (75) بنسبة (44.6\%)، ومن 10 دورات فأكثر (93) بنسبة (55.4\%)، أما من ناحية الوظيفة فكان عدده من حيث كونه ضباط بلغ عددهم (68) بنسبة (40.5\%)، ومن هم أفر اد بلغ عددهم (57)

$$
\text { بنسبة (33.9\%)، و المدنيين بلغ (43) سنوات (25.6\%). }
$$

أداة البحث و إجراعات تطبيقها: اعتمد الباحث على الاستبانة كأداة لجمع البيانات والمعلومات المتعلقة بالبحث، حيث تعد الاستبانة من أكثر أدوات البحث العلمي استخدمًا وشيوعًا فى البحوث الوصفية، ويعرض الباحث هنا خطوات بناء أداة البحث المنمثلة وفقاً للخطو ات التالية:

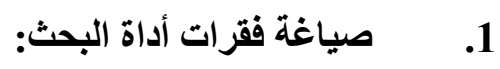
بالعودة الى الدر اسات السابقة التي قام الباحث بذكر ها في متن الدر اسة و التي تتحدث عن التدريب و عناصره المختلفة وقياس الأداء، وبحكم در استه الجامعية في هذا الجانب؛ للاستفادة منها حيث قام الباحث بتصميم أداة الاستبانة لهذا البحث، وتألفت على عدد من الأسئلة موجهة لجميع أفر اد عينة البحث، 
بهدف الحصول على المعلومات حول ظاهرة معينة؛ لأنّ أداة الاستبانة تُعدّ أكثر الأدوات استخدامًا لدى الباحثين لمعرفة آراء المبحوثين واتجاهاتهم المرتبطة بالو اقع، وكذلك بو اسطتها يمكن التعرف على الظاهرة المطلوب در استها. وقد تم صباغة فقر ات أداة البحث حسب ما يلي: أ. مر اعاة أن تخدم هذه الفقرة الأهداف المطلوب تحقيقها و التي تعمل على تحقيق أهداف البحث. ب. تم صياغة العبار ات بحيث تكون و اضحة ومفهومة ومناسبة لجميع أفر اد العينة. ج. روعي في اختيار العبار ات التنوع، و أن يكون لكل عبارة هدف محدد يقيس قيمة محددة من الأداة.

\section{2.}

تم صياغة تعليمات أداة البحث بغرض تعريف أفر اد عينة البحث على الهدف من البحث، وقد روعي فى ذلك أن تكون الفقر ات واضحة ومفهومة وملائمة لمستو اهم، كما تضمنت تعليمات أداة البحث التأكيد على كتابة البيانات الخاصة بمتغير ات البحث. وكذلك طلب منهم قر اءة العبار ات بدقة ومعرفة المقصود من كل عبارة مع تدوين الاستجابة في المكان المخصص.

\section{3. وصف أداة البحث: تم صياغة الاستبانة في صورتها الأولية على النحو التالي:} أ. ـاليانات الثخصية والوظيفية عن أفراد العينة ويتضمن الجزء الأول: تضمن البيانات الثخصية و الوظيفية لأفر اد العينة، حسب متغير ات الدر اسة المستقلة (المؤهل العلمي- الدور ات التدرييةـ الوظيفة). ب. اثتتملت الأداة في صورنها النهائية على مجمو عة من العبار ات بلغ عددها (19) عبارة، موز عة على أربعة محاور: الأول: التخطيط، وييلغ عدد عباراته (6) عبارة، والثاني: التنظيم، وييلغ عدد عبار اته (5) عبارة، و الثالث: التوجيه، وييلغ عدد عبار اته (4) عبارة، و الر ابع: الرقابة، ويبلغ عدد عبار اته (4) عبارة. ج. اعطى الباحث لكل فقرة وزنًا مدرجًا وفق مقياس ليكرت الثلاثي، وقام الباحث باستخدام العبارات (مو افق، مو افق بدرجة متوسطة، غير مو افق) بالنسبة لدرجة(الاختلاف) وتمثل رقميًا بالأعداد (1,2,3) على

\section{التوالي، كما هو موضح في ملحق (1).}

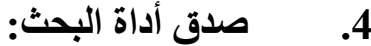

بقصد به أن تقيس الأداة ما وضعت لقياسه وتحقق الأهداف التي وضعت لها قبل إعدادها حيث أن الأداة التي تتمتع بالصدق تقيس الوظيفة التي وضعت من أجلها ولا تقيس شيئًا آخر بدلا منها أو بالإضافة إليها، وتحقبقا لصدق أداة الدر اسة تم استخدام. الأداة تم تصميمها بمعرفة الباحث، وتم عمل تقنين لها من قبل المحكمين، لكي تناسب قسم التدريب بإدارة الدفاع المدني بالعاصمة المقدسة. 
لذللك تم عرضها على مجمو عة من المحكمين المختصين من ذوي الخبرة و الكفاءة و البالغ عددهم (2) محكمين، للحكم عليها، ليصبح المقياس في صورته النهائية يتكون من قسمين.

\section{إجراءات تطبيق أداة البحث:}

بعد أن وضعت أداة البحث في صورتها النهائية، وأصبحت جاهزة للتطبيق، قام الباحث باستنذان سعادة المشرف على البحث لنطبيقها، ونم أخذ توجيه خطاب من الدراسات العليا بجامعة الملك عبدالعزيز إلى إدارة قسم

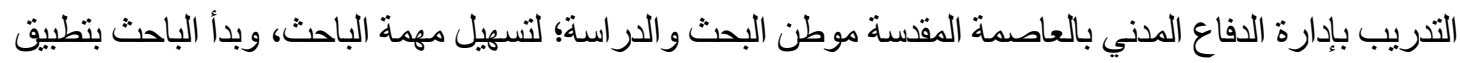
الاستبانة على مجتمع بحثة، حيث قام بإعداد جلول زمني لعملية التطبيق، حيث نم تخصيص ثلاثة أسابيع للنطبيق، وحلث ذلك خلال الفصل الدر سي الثاني 1442/01441.

تطبيق أداة البحث: - n

تم توزيع الاستبيانات عبر "جوجل فورم" على أفراد العينة من العاملين بالقسم، إلا أنه لم بيتجب

$$
\text { منهم إلا (168) من المنسوبين. }
$$

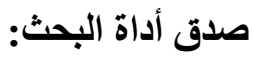
وتحقيقا لصدق أداة البحث تم استخدام التالي:

$$
\text { 1. الصدق الظاهري (الخارجي) للأداة: }
$$

الصدق الظاهري: تم تحديد الصدق الظاهري للمقياس من خلال عرض الفقرات موزعة حسب المحور الذي تتنمي له كل فقرة، على مجموعة من المحكمين المختصين من ذوي الخبرة و الكفاءة والبالغ عددهم (2) محكمين و هو ما تم إجر اءه لتقنين الأداة ومدى وملاءمتها للتطبيق.

\section{2. صدق الاتساق الاخخلي للأداة (الصدق البنائي):} تم التحقق من صدق الاتساق الداخلي فى كل عبارة من عبارات أداة البحث، من خلال ايجاد مدى ارتباط كل عبارة و الدرجة الكلية لجميع العبار ات، و التأكد من عدم التداخل بينها، وتحقق الباحث من ذلك بإيجاد معاملات الارتباط باستخدام معامل الارتباط بيرسون، وللحكم على سلامة صدق البناء تم اعتماد رفض العبارة إذا ما كان معامل الارنباط أقل من (0.30)، وجدول رقم (2) يوضح ذلك: 


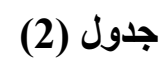

الاتساق الاخلي لأداة البحث

\begin{tabular}{|c|c|c|c|c|c|c|c|}
\hline \multicolumn{8}{|c|}{ معاملات الارتباط للمحور } \\
\hline الرابع - ل ابع & م & 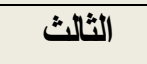 & b & الثاني & b & الأول & p \\
\hline$* * 0.849$ & 1 & $* * 0.840$ & 1 & $* * 0.844$ & 1 & $* * 0.815$ & 1 \\
\hline$* * 0.864$ & 2 & $* * 0.874$ & 2 & $* * 0.819$ & 2 & $* * 0.839$ & 2 \\
\hline$* * 0.914$ & 3 & $* * 0.850$ & 3 & $* * 0.812$ & 3 & $* * 0.817$ & 3 \\
\hline$* * 0.867$ & 4 & $* * 0.798$ & 4 & $* * 0.806$ & 4 & $* * 0.820$ & 4 \\
\hline & & & & $* * 0.791$ & 5 & $* * 0.830$ & 5 \\
\hline & & & & & & $* * 0.807$ & 6 \\
\hline
\end{tabular}

\section{** دالة إحصائيًا غذ مستوى دلالة}

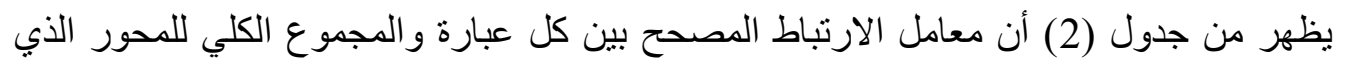
ينتمي له أن درجة كل عبارة في معاملات الارتباط المصحح لهحاور الاستبانة، ضمن المدى المسموح به (أكبر

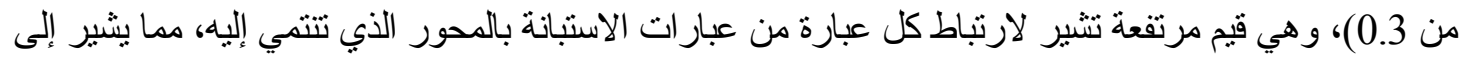

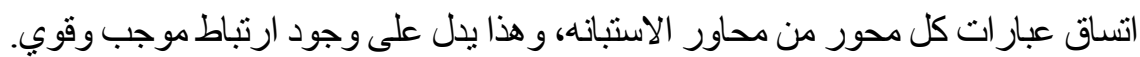
و عليه تصبح الاستبانة في صورتها النهائية مكونه من أربعة محاور رئيسية و التي تم تحديدها سابقاً،

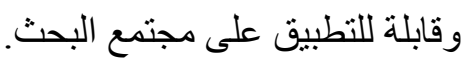

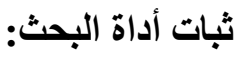
يعد الثبات من الثروط السيكومترية التي يجب تو افر ها في الأداة الجيدة، ويقصد به حصول الأفر اد على نفس الدرجات إذا ما أعيد تطبيقه عليهم بنفس الظروف، وللتأكد من ثبات الأداة ستقوم الباحث باستخدام (معادلة ألفا كرونباخ Cronbach'aAlpha)، حيث تطبق المعادلة لقياس الصدق البنائي، والجدول رقم (3) يوضح معاملات الفا كرونباخ لعبار ات البحث.

جدول (3) (2)

معامل الثبات كرونباخ ألفا "a م" لعبارات البحث

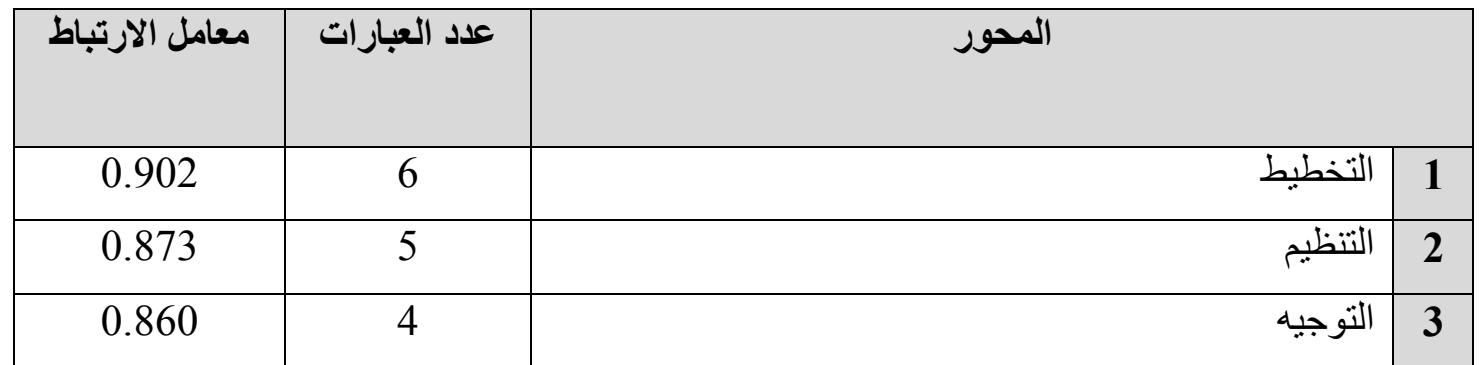


المجلة الدولية لنشر البحوث والدراسات

International Journal of Research and Studies Publishing

ISSN: 2709-7064

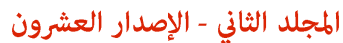

تأريخ الإصدار: 20 حزيران 2021م

\begin{tabular}{|c|c|c|c|}
\hline معامل الارتباط & عدد العبارات & المحور & \\
\hline 0.897 & 4 & الرقابة & 4 \\
\hline 0.963 & 19 & الثبات الكلح & \\
\hline
\end{tabular}

يظهر الجدول (3) بأن معاملات الثبات المقدرة بمعادلة كرونباخ ألفا" ه " للعينة بلغت درجة الثبات الكلية للمقياس (0.963)، و هي قيم مرتفعة ومقبولة لأغر اض تطبيق البحث، وتنثير إلى أن الأداة تتمتع بدرجة عالية من الثبات، وبالتالي يمكن الاعتماد على النتائج و الوثوق بها.

\section{الأساليب والمعالجات الإحصائية المستخدمة في البحث:}

سيتم تفريغ المعلومات خلال الاستبانات المسترجعة باستخدام الحاسب الآليوأجراء المعالجة الإحصائية باستخدام برنامج (spss) و المتمثلة كما يلي: (1) معامل ارتباط بيرسون، لحساب لاتساق الداخلي. (2) استخراج معامل الثبات، طبقاً لمعادلة ألفا كرونباخ(Cronbach Alpha) لحساب الثبات لعبارات الاستبانة.

$$
\text { (3) التكر ارات والنسب المئوية في وصف عينة البحث. }
$$

(4) المتوسطات الحسابية، والانحر افات المعيارية؛ لحساب متوسطات عبار ات الاستبيان، وكذلك الدرجات الكلية و الدرجات الفر عية للاستبانة بناء على استجابات أفر اد عينة البحث، ومدى تشتت استجابات أفر اد

$$
\text { عينة الدر اسة عن متوسطاتها. }
$$

(5) استخدام تحليل التباين، للتعرف على دلالة ما قد يوجد من فروق بين المتوسطات الحسابية لاستجابات أفر اد عينة البحث، وفقاً للمتغير (المؤهل الدراسي_الدورات التدريبية ـالوظيفة). (6) وتم استخدام معيار الحكم على الدراسة كما يلي:

$$
\frac{3-1}{3}=\frac{2}{3}=0.66 \quad \text { طول الفئة = مدى الفئة/ عدد الخيار }
$$

و وبناءً على ذلك يكون الحكم على درجة تو افر فقر ات الاستبانه من جانب أفر اد العينة لديهم وفق معيار

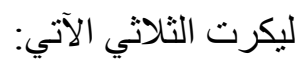




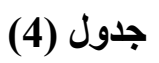

معيار الحكم لتقير درجة الموافقة على فقرات الاستباتة من أفراد العينة

\begin{tabular}{|c|c|}
\hline لرجة تحقق الممارسة & المتوسط \\
\hline غير موافق & من ا إلى أفل من 1.66 \\
\hline مو افق بدرجة متوسطة & من 1.67 إلى أقلى من 2.33 \\
\hline موافق & من 2.34 إلى أقل من 3 \\
\hline
\end{tabular}

الفصل الرابع مناقشة نتائج البحث، وتوصياته ومقترحاته مناقشة نتائج البحث وتقسير ها:

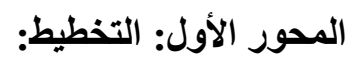

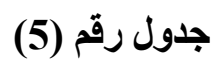

حساب المتوسطات الحسابية والاتحرافات المعيارية حول " التخطيط"

\begin{tabular}{|c|c|c|c|c|c|}
\hline 司: & الموافقة & المعياري & الحستوسي & العبارة & p \\
\hline 1 & مو افق & 0.545 & 2.70 & ووراضحة داخل الاهداف الإدارية بطريقة جيدة & 1 \\
\hline 4 & مو افق & 0.624 & 2.58 & 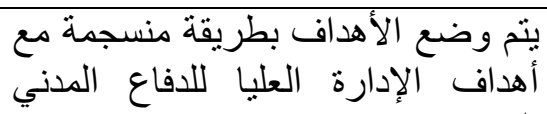 & 2 \\
\hline 3 & مو افق & 0.660 & 2.58 & 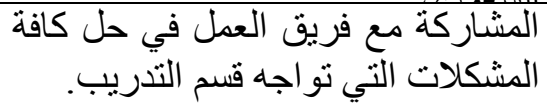 & 3 \\
\hline 6 & موافق & 0.665 & 2.53 & سياستات العمل. سياسات مكتوبة تتو افق مع & 4 \\
\hline 5 & مو افق & 0.656 & 2.54 & سياسات العمل سياسات مكافتهوبة تتو افق مع & 5 \\
\hline 2 & مو افق & 0.623 & 2.64 & والقسم تبالقم بالمرونة لتحقيق أهداف العمل & 6 \\
\hline \multicolumn{3}{|c|}{ موافق } & 2.60 & \multicolumn{2}{|l|}{ المتوسط العام } \\
\hline
\end{tabular}

يتضح من الجدول (5) النتائج المتعلقة بالمحور الأول " التخطيط " حيث أن المتوسط العام قد بلغ (2.60)،

$$
\text { مما يثير إلى المو افقة عليها بدرجة (مو افق) بين أفر اد عينة البحث؛ }
$$


كما أن جميع المتوسطات الحسابية لإجابات أفراد العينة على عبار اته انحصرت بين (2.70- 2.53) مما يثثير إلى مستوى موافقة بين (موافق) وهى تعد درجة مرتفعة، حيث جاءت عبارات المحور الأول مرنبة على النحو الذى يشير إلى تحققها في بيئة العينة ووفقاً لآراء العينة على النحو التالي: 1. المرتبة الأولي: يتم تحديد الأهداف الإدارية بطريقة جيدة وو اضحة داخل قسم التنريب، بمتوسطحسابي(2.70). 2. المرتبة الثانية: يوجد بالقسم خطط لتحقيق أهداف العمل و القسم تتسم بالمرونة. بمتوسط حسابي(2.64). 3. المرتبة الثالثة: المشاركة مع فريق العمل في حل كافة المشكلات التي نواجه قسم التدريب، بمتوسط

$$
\text { حسابي(2.58). }
$$

4. المرتبة الر ابعة: يتم وضع الأهداف بطريقة منسجمة مع أهداف الإدارة العليا للافاع المنني السعودي، بمتوسط

$$
\text { حسابي(2.58). }
$$

5. المرتبة الخامسة: يوجد بالقسم سياسات مكتوبة تتو افق مع سياسات العمل وأهدافه بمتوسط حسابي(2.54). 6. المرتبة السادسة: يوجد بالقسم سياسات مككوبة نتو افق مع سياسات العمل، بمتوسط حسابي(2.53) ويمكن تفسير هذا النتائج التحديد الدقيق لأهداف التخطيط وصياغتها بطريقة تتفق مع رؤية القسم و الإدارة العامة بساهم في تحقيق المشاركة الفعالة و الايجايية لكافة المنسوبين لتحقيق أهداف القسم، وهذا يدل على التعاون و التر ابط بينهم.

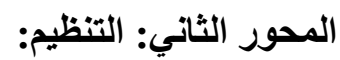

\section{جدول رقم (6) - (6)}

\begin{tabular}{|c|c|c|c|c|c|}
\hline 司 $\mathrm{J}$ : & الموافقة & 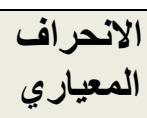 & المتوسطي & 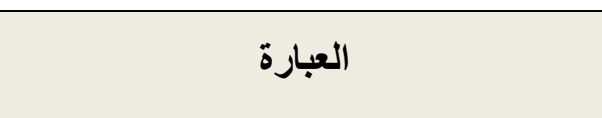 & b \\
\hline 5 & 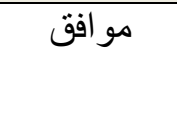 & 0.633 & 2.58 & ويوجد توزيع للمهام بين أعضاء القسم بعدالة & 1 \\
\hline 4 & مو افق بشدة & 0.620 & 2.60 & أعضوجد تفويض اللصم. & 2 \\
\hline 2 & 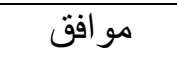 & 0.584 & 2.67 & يوجد توصيف للوظائف والأعمال داخل & 3 \\
\hline 3 & 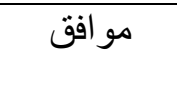 & 0.570 & 2.65 & الاقوجد بالقسم مسؤول يقوم بتنسيق العمل مع & 4 \\
\hline 1 & 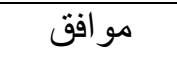 & 0.566 & 2.70 & بوجد آليات لإخبار المنسوبين بالأوامر & 5 \\
\hline \multicolumn{3}{|c|}{ موافق } & 2.64 & \multicolumn{2}{|l|}{ المتوسط العام } \\
\hline
\end{tabular}

حساب المتوسطات الحسابية والاتحرافات المعيارية حول " التنظيم "

بتضح من الجدول (6) النتائج المتعلقة بالمحور الثاني " التنظيم " حيث أن المتوسط العام قد بلغ (2.64)،

$$
\text { مما يثير إلى المو افقة عليها بدرجة (مو افق) بين أفر اد عينة البحث؛ برك }
$$


كما أن جميع المتوسطات الحسابية لإجابات أفراد العينة على عبار اته انحصرت بين (2.70-2.58) مما يشير إلى مستوى موافقة بين (مو افق) و هي تعد درجة مرتفعة، حيث جاءت عبار ات المحور الثناني مرتبة على النحو الذي يشير إلى تحققها في بيئة العينة ووفقاً لآراء العينة على النحو التالي: 1. المرتبة الأولي: يوجد آليات لإخبار المنسوبين بالأوامر والتعليمات، بمتوسط حسابي (2.70). 2. المرتبة الثانية: يوجد توصيف للوظائف و الأعمال داخل القسم. بمنوسط حسابي(2.67). 3. المرنبة الثالثة: يوجد بالقسم مسؤول يقوم بتنسيق العمل مع الاقسام الأخري، بمتوسط حسابي(2.65). 4. المرنبة الر ابعة: يوجد تفويض للصلاحيات موز عة على أعضاء القسم، بمنوسط حسابي(2.60). 5. المرتبة الخامسة: يوجد نوزيع للمهام بين أعضاء القسم بعدالة وموضو عية، بمتو سط حسابي(2.58). وربما يرجع ذللك إلى التنظيم الإداري الجيد بحكم طبيعة عملها كمؤسسة عسكرية تقوم على الضبط والتنظيم وتوزيع المهام وتفويض الصلاحيات، والتوزيع الجيد حسب التوصيف للمهام، وحسن الاختيار المنسوبين للعمل.

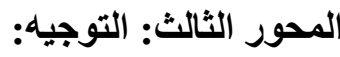

$$
\text { جدول رقم (7) (1) (1) (1) }
$$

حساب المتوسطات الحسابية والانحر افات المعيارية حول "التوجيه "

\begin{tabular}{|c|c|c|c|c|c|}
\hline 牙 & الموافقة & المعياري & الحستوسطي & 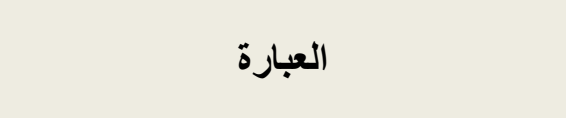 & r \\
\hline 4 & مو افق & 0.593 & 2.59 & كافة التعليمات و الأمور بالقسم و اضحة & 1 \\
\hline 2 & 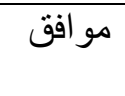 & 0.612 & 2.60 & لتحقيق أهليفافهر و واضحة لتوجيه المنسو بين & 2 \\
\hline 3 & 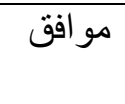 & 0.669 & 2.59 & الأوجامر منسق يقوم بتوضيمات للمنسوبين الغامض من & 3 \\
\hline 1 & 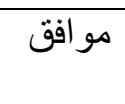 & 0.532 & 2.67 & القبوجد ومتنوعة اليب اتصال مناسبة بين أعضاء & 4 \\
\hline \multicolumn{3}{|c|}{ موافق } & 2.61 & \multicolumn{2}{|l|}{ المتوسط العام } \\
\hline
\end{tabular}

يتضح من الجدول (7) النتائج المتعلقة بالمحور الثالث" التوجيه" حيث أن المنوسط العام قد بلغ (2.61)، مما يثير إلى المو افقة عليها بدرجة (موافق) بين أفر اد عينة البحث؛ كما أن جميع المثوسطات الحسايية لإجابات أفر اد العينة على عبار اته انحصرت بين (2.67- 2.59) مما يثير إلى مستوى مو افقة بين (مو افق) وهى تعد درجة مرتفعة، حيث جاءت عبارات المحور الثالث مرنبة على النحو الذى يشير إلى تحققها في بيئة العينة ووفقاً لآراء

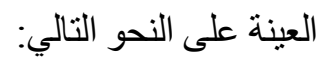

1. المرتبة الأولي: يوجد اساليب اتصال مناسبة بين أعضاء القسم ومتنو عة، بمتوسط حسابي(2.67). 
2. المرتبة الثانية: وجود تعليمات واضحة لتوجيه المنسو بين لتحقيق أهدافهر. بمنوسط حسابي(2.60). 3. المرتبة الثالثة: يوجد منسق يقوم بتوضيح الغامض من الأوامر والتعليمات للمنسوبين، بمتوسط

$$
\text { حسابي(2.59). }
$$

4. المرتبة الرابعة: كافة التعليمات و الأمور بالقسم واضحة، بمنوسط حسابي(2.59) وربما ترجع تلك النتائج لوجود اساليب تو اصل بين المنسوبين وتعليمات واضحة لتوجيهم إلى الفضل و الأصح بوضوح وفق تعليمات محدده، و هذا ساهم في فهم طبيعة العمل القائم على التخطيط والتنظيم، والتوجيه وفق إدارة للقسم تتفق مع رؤية

$$
\text { وطبية المؤسسة التي ينتمي لها القسم. }
$$

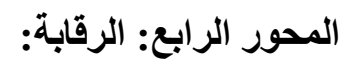

\section{جدول رقم (8)}

\begin{tabular}{|c|c|c|c|c|c|}
\hline 武 & الموافقة & الانـحراف & الحستبي & 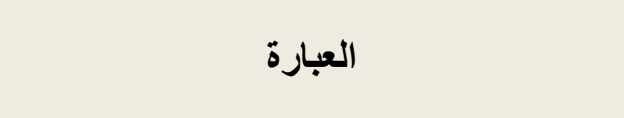 & م \\
\hline 1 & 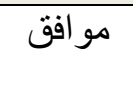 & 0.619 & 2.61 & توجد أساليب رقابية على المنسوبين تنسجم مع & 1 \\
\hline 3 & 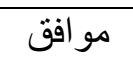 & 0.664 & 2.55 & توجد أساليب رقابية تتسم بالسهولة و الوضوح. & 2 \\
\hline 4 & 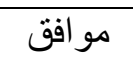 & 0.704 & 2.54 & يوجد برنامج رقابي واضح المعالم لكافة & 3 \\
\hline 2 & 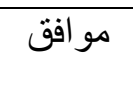 & 0.663 & 2.56 & لتنفوجذ الاساليب الرقابية بكفاءة لاسترجاع المعلومات & 4 \\
\hline \multicolumn{3}{|c|}{ موافق - } & 2.56 & \multicolumn{2}{|l|}{ المتوسط العام } \\
\hline
\end{tabular}

حساب المتوسطات الحسابية والاتحر افات المعيارية حول " الرقابة مول

يتضح من الجدول (8) النتائج المتعلقة بالمحور الرابع " الرقابة" حيث أن المنوسط العام قد بلغ (2.56)، مما يثير إلى الموافقة عليها بدرجة (موافق) بين أفر اد عينة البحث؛ كما أن جميع المنوسطات الحسابية لإجابات

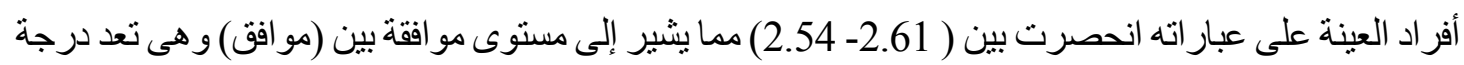
مرتفعة، حيث جاءت عبار ات المحور الرابع مرنبة على النحو الذى يثنير إلى تحققها في بيئة العينة ووفقاً لآراء

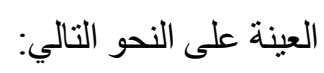

1. المرتبة الأولي: توجد أساليب رقابية على المنسوبين تنسجم مع العمل وأهدافه، بمتوسط حسابي(2.61). 2. المرتبة الثانية: يوجد طرق مختلفة لاسترجاع المعلومات لتنفيذ الاساليب الرقابية بكفاءة. بمتوسط بوسط

$$
\text { حسابي(2.56). }
$$

3. المرتبة الثالثة: توجد أساليب رقابية تتسم بالسهولة و الوضوح، بمنوسط حسابي (2.55). 4. المرتبة الر ابعة: يوجد برنامج رقابي و اضح المعالم لكافة المنسوبين، بمتوسط حسابي(2.54). 
ويمكن تفسير ذلك إلى طبيعة العمل داخل القسم والتي تتبع من طبيعة المؤسسة عامة وهي إدارة الدفاع الدنني وطبيعة التنظيم و الدقة، و هذا يحتاج إلى نظام صارم في التعامل مع الأحداث وهذا قـ انعكس على القسم وبالتالي نجد نظام رقابي هدفه تحقيق الصالح العامة للمؤسسة و المجتمع.

دلالة الفروق حسب متغير المؤهل:

للتحقق من صحة الفرضية، وللكثف عن الدلالة الاحصائية للفروق بين استجابات أفراد عينة البحث موطن الدراسة وفقاً لمتغيري المؤهل الدراسي، ومتغير الوظيفة، فقد تم استخدام اختبار "ت" للمقارنة بين منوسطين مستقلين، و الجدول (9) يوضح ذلك.

\section{جدول (9)}

نتائج اختبار (ت) للتعرف على دلالة الفروق بين منوسطات استجابات أفر اد عينة حول درجة تقييم أداء الإدارة الرياضية بقسم لتدريب للإدارة العامة للدفاع المدني بالعاصمة المقسة، والتي تعزى لاختلاف متغيري (المؤهل الدر اسي)

\begin{tabular}{|c|c|c|c|c|c|c|}
\hline مستوى الدلالة & قيمة & الانحرياري & الحستوسطي & العدد & القئات & المحور \\
\hline \multirow{2}{*}{ غير دالة 0.496 غ } & \multirow{2}{*}{$0.682-$} & 3.271 & 15.35 & 65 & بكالوريوس & \multirow{2}{*}{ التخطبط } \\
\hline & & 2.994 & 15.69 & 103 & در اسات عليا & \\
\hline \multirow{2}{*}{ غير دالة 0.212} & \multirow{2}{*}{$1.254-$} & 2.697 & 12.91 & 65 & بكالوريوس & \multirow{2}{*}{ التنظيم } \\
\hline & & 2.228 & 13.39 & 103 & در اسات عليا & \\
\hline \multirow{2}{*}{ غير دالة 0.606} & \multirow{2}{*}{$0.517-$} & 2.210 & 10.34 & 65 & بكالوريوس & \multirow{2}{*}{ التوجيه } \\
\hline & & 1.909 & 10.50 & 103 & در اسات عليا & \\
\hline \multirow{2}{*}{ غير دالة 0.181} & \multirow{2}{*}{$1.343-$} & 2.589 & 9.95 & 65 & بكالوريوس & \multirow{2}{*}{ الرقابة } \\
\hline & & 2.127 & 10.45 & 103 & در اسات عليا & \\
\hline
\end{tabular}

(**) دالة عند مستوى دلالة (0.05) يتضح من الجدول (9) عدم وجود فروق ذات دلالة إحصائية عند مستوى (0.05) بين منوسطات استجابات أفر اد العينة حول محاور الاستبانة الأربعة، و التي تعزى لاختلاف المؤهل الدراسي. 
دلالة الفروق حسب متغير الدورات التدريبية:

جدول (10)

نتائج اختبار (ت) للتعرف على دلالة الفروق بين منوسطات استجابات أفر اد عينة حول درجة تقييم أداء الإدارة الرياضية بقسم لتدريب للإدارة العامة للدفاع المدني بالعاصمة المقدسة، و التي تعزى لاختلاف متغيري (الدورات التدريبية)

\begin{tabular}{|c|c|c|c|c|c|c|}
\hline مستوى الدلالة & قيمة & الانحراف & المتوسط & 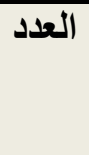 & الفئات & المحور \\
\hline$* * 0.006$ & \multirow[t]{2}{*}{$2.809-$} & 3.391 & 14.83 & 75 & أقل من 5 دورات & \multirow[t]{2}{*}{ التخطبط } \\
\hline دالة & & 2.718 & 16.15 & 93 & من 10 دور ات فأكثر & \\
\hline & \multirow{2}{*}{$3.098-$} & 2.692 & 12.57 & 75 & أقلّ من 5 دور ات & \multirow[t]{2}{*}{ التنظيم } \\
\hline دالة ل & & 2.062 & 13.71 & 93 & من 10 دور ات فأكثر & \\
\hline & \multirow{2}{*}{$2.654-$} & 2.263 & 9.99 & 75 & أقل من 5 دورات & \multirow{2}{*}{ التوجيه } \\
\hline دالة ل & & 1.740 & 10.81 & 93 & من 10 دور ات فأكثر & \\
\hline & \multirow[t]{2}{*}{$2.386-$} & 2.543 & 9.79 & 75 & أقلّ من 5 دور ات & \multirow[t]{2}{*}{ الرقابة } \\
\hline دالة ل & & 2.063 & 10.63 & 93 & من 10 دور ات فأكثر & \\
\hline
\end{tabular}

(**) دالة عند مستوى دلالة (0.05) يتضح من الجدول(10) وجود فروق ذات دلالة إحصائية عند مسنوى(0.05) بين متوسطات استجابات أفر اد العينة حول محاور الاستبانة الأربعة، والتي تعزى لاختلاف الدورات التدريبية.

دلالة الفروق حسب متغير الوظيفة:

للتحقق من صحة الفرضية، وللكثف عن الدلالة الاحصائية للفروق بين استجابات أفراد عينة البحث موطن الدراسة وفقاً لمتغير الوظيفة، فقا تم استخدام اختبار "ف" للمقارنة بين متوسطين مستقلين، والجدول (11) يوضح ذلك. 
جدول (11)

نتائج تحليل التباين الأحادي للفروق بين متو سطات استجابات العينة لمتغير (الوظيفة)

\begin{tabular}{|c|c|c|c|c|c|}
\hline مستوى الدلالة & "فيمة" & المربعات & مجموع المربعات & مصدر التباين & المحاور \\
\hline \multirow{3}{*}{ غير دالة 0.196} & \multirow{3}{*}{1.647} & 15.692 & 31.383 & بين & \multirow{3}{*}{ التخطيط } \\
\hline & & 9.527 & 1572.022 & داخل & \\
\hline & & & 1603.405 & المجموع & \\
\hline \multirow{3}{*}{ غير دالة 0.099} & \multirow{3}{*}{2.346} & 13.562 & 27.123 & بين & \multirow{3}{*}{ التنظيم } \\
\hline & & 5.782 & 953.996 & داخل & \\
\hline & & & 981.119 & المجموع & \\
\hline \multirow{3}{*}{ غير دالة 0.300} & \multirow{3}{*}{1.213} & 4.967 & 9.934 & بين & \multirow{3}{*}{ التوجيه } \\
\hline & & 4.094 & 675.471 & داخل & \\
\hline & & & 685.405 & المجموع & \\
\hline \multirow{3}{*}{$\begin{array}{c}0.327 \\
\text { غير دالة }\end{array}$} & \multirow{3}{*}{1.124} & 6.048 & 12.096 & بين & \multirow{3}{*}{ الرقابة } \\
\hline & & 5.381 & 887.898 & داخل & \\
\hline & & & 899.994 & المجموع & \\
\hline
\end{tabular}

من الجدول السابق رقم (11) أن قيمة (ف) غير دالة إحصائياً عند مستوى دلالة (0.05) لكافة محاور البحث وفقًا متغير الوظيفة ماعدا كل من:

$$
\begin{aligned}
& \text { المحور الأول: التخطيط، حيث مسنوى دالة(0.196) } \\
& \text { المحور الثاني: التنظيم، حيث مستوى دالة(0.099) } \\
& \text { المحور الثالث التوجيه، حيث مستوى دالة(0.300) }
\end{aligned}
$$

المحور الر ابع: الرقابة، حيث مستوى دالة(0.327) مما يدل على عدم وجود تأثثير لمتغير الوظيفة.

$$
\text { استنتاجات البحت: }
$$

1. . وجود إدر اك في مستوى الوعي لدى أفراد العينة بأهمية قسم التدريب، ودوره الحبوي في تحقيق

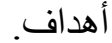

2. وجود قو اعد بيانات لاى القسم وخطط ذات اهداف تنسجم مع أهداف الإدارة العامة للدفاع المدني. 
3. وجود اهتمام بشكل كامل لاستغلال بالإدارة الجيدة داخل القسم تقوم على أسس الإدارة العلمية الصحيحة.

4. وجود قصور في بعض الجوانب الخاصة بالتدريب مثل أى عمل بشرى ولكنها لا تؤثر على الداء و القيام به على أفضل كفاءة.

5. وجود عجز في المو ارد المادية والبشرية بشكل قد يسهم فى مساهمة القسم في القيام بمهامه لكن حسن الادارة وتوزيع المهام يساعد على تحقيق العمل و إدارته بكفاءة.

\section{توصيات البحث:}

في ضوء ما أظهرته نتائج هذا البحث بوصي الباحث بالآتي: 1. ضرورة العمل على إصدار السياسات و اللوائح و التشريعات المناسبة للتخطيط الجيد للقسم. 2. ضرورة إصدار القو انين، لكي تتيح التنظيم و التخطيط و الرقابة بطريقة جيده وسليمه 3. يجب العمل على توفير قو اعد البيانات الخاصة بإمكانات القسم المادية و البشرية. 4. تسهيل الإجر اءات التي تمكن القسم من زيادة كفاءة العمل داخلة و الارتقاء بمستوى العمل داخله. 5. إنشاء مر اكز متخصصة بهدف زيادة التخطيط و التنظيم داخل القسم و الاقسام المشابهة له بالإدارة. 6. ضرورة وضع بر امج لنشر الوعي لدى المنسوبين بأهمية القسم ودوره الحيوي. 7. ضرورة دعم هذه القسم بكو ادر بشرية مؤهلة متخصصة.

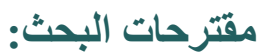

1. ضرورة إجر اء در اسات لتقيم الإداء داخل إدار ات اخرى بالإدارة العامة للدفاع الدني. 2. ضرورة صياغة در اسات لمعرفة معوقات اقسام التدريب بإدارات الدفاع المدني السعودي. 3. ضرورة إجر اء در اسة لتوعية المنسوبين لإدارة الدفاع المدني عامة وقسم التدريب خاصة بأهميته.

إبر اهيم، بدرية محمود محمد(2006). إثر التدريب على تطوير مهار ات العاملين، دراسة تطبيقية على معهد علوم نظم المعلومات بجهاز الثرطة، رسالة ماجستير غير منشورة، أكاديمية السادات للعلوم

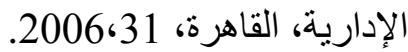

أحمد، عبد الله سعيد عبد القادر. (2018). تقييم أداء البنوك المصرية باستخدام نظام التقييم المصرفي الأمريكي: در اسة مقارنة بين البنوك العامة والخاصة .المجلة العلمية للار اسات التجارية و البيئية: جامعة

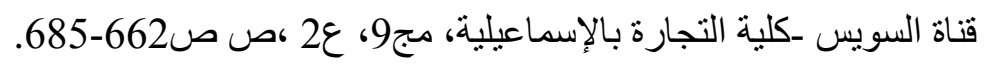


آدم، حسابو احمد حسابو. (2016). أثر التدريب في تطوير أداء العاملين: دراسة حالة الصندوق القومي للتأمين الصحي "و لاية النيل الأبيض ."مجلة كلية دلتا العلوم و التكنولوجيا: كلية دلتا العلوم و التكنولوجيا، ع 3 ، ص ص ص 181-184. إمام، محمد بيومي محمد (2019). تقييم الأداء كمدخل لرفع كفاءة أداء العاملين: در اسة ميدانية مقارنة بين شركات صناعة الغزل و النسيج المصرية وشركات صناعة الغزل و النسيج الأجنبية .المجلة العلمية للار اسات التجارية و البيئية: جامعة قناة السويس -كلية التجارة بالإسماعيلية، مج10، ع1 ، ص ص ص $.530-507$

حامد، عمرو. (2009). تقييم الأداء المؤسسي في الوحدات الحكومية .أعمال ملتقيات وندوات: قياس و تقييم الأداء كمدخل لتحسين جودة الأداء المؤسسي: المنظمة العربية للتنمية الإدارية، القاهرة: المنظمة العربية للتنمبة الإدارية، 109 - 158. حسام الدين، طلحة مطر (1997). مقدمة في الإدارة الرياضة، القاهرة: مركز الكتاب للنشر. حميد، عبد العزيز جاسم (2000). تأثثر البرامج التدريبية على الرضاء الوظيفي، رسالة ماجسنير غير منشورة، اكاديمية السادات لعلوم الإدارية، القاهرة. الخطيب، رداح، الخطيب، أحمد(2006). التدريب الفعال، اربد: عالم المكتب الحديث. الداهري، عبد الوهاب مطر(1991). تقييم المشاريع ودراسات الجدوى الاقتصادية، عن دار الحكمة

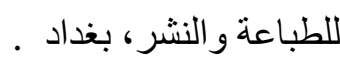
سلمان، احمد هاثثم، (2000). إدارة الأداء، بحث كجزء من متطلبات مـادة إدارة المـوارد البشرية

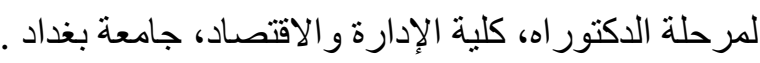
عبيدات، ذوقان؛ و آخرون (2013) البحث العلمي مفهومه و أدو اته وأساليبه، عمان: دار الفكر. العسيلي، ماجد(2005): التقييم الإداري لأداء الاتحادات الرياضية الأولمبية في الأردن، رسالة دكتور اه غير منشورة، كلية التربية الرياضية، الجامعة الأردنية، عمان. العطيات، خالد محمود، والسعود، حسن. (2009). تقييم الأداء للاتحادات الرياضية الأردنية للعام

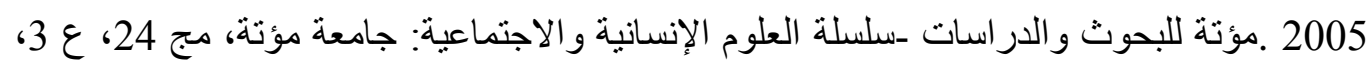
ص علي، محمد مسلم حسن، و عبد الرحيم، محمد عباس محمد. (2009). الإدارة الإلكترونية كمدخل لتطوير بعض وظائف الإدارة بجامعة تبوك ـمجلة التربية: جامعة الأزهر - كلية التربية، ع 143، ج 3 ،ص ص الكعبي، سعيد بن خميس. (2002). أثر التدريب على تنمية الإدارة المحلية، رسالة ماجستير غير منشورة، اكاديمية السادات للعلوم الإدارية، القاهرة. 
• مساعدة، ايمان عقلة(2008). استراتيجية أداء المعلمين، دبي: منشورات مدرسة محمد بن راشد أل مكتوم للتعليم الثنانوي.

هيا، علي يونس، و الثامسي، سالم راشد ديب. (2009). قياس أثر التدريب في أداء العاملين: دراسة

ميدانية على مديرية التربية والتعليم بمحافظة البريمي في سلطنة عمان ـمجلة جامعة نشرين للبحوث

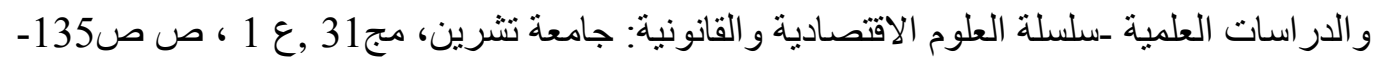

هاثش، رشاد مهدي، أنمار حاجي أمين، (1993). تقييم كفاءة الأداء لمعهـل اربيـل للغزل والنسيج الصوفي، مجلة تنمية الر افدين، المجلد 110 (1، عدد اء، كلية الإدارة والاقتصاد، جامعة الموصل.

Doi: doi.org/10.52133/ijrsp.v2.20.9 